\title{
Carbonation and silicification of peridotites in the San Juan de Otates ultramafic-mafic complex (Guanajuato, Central Mexico)
}

\author{
C.C. LÁZARO-PAZ ${ }^{1}, *$ V. COLÁs ${ }^{2}$, N.A. PINEDA- \\ RODRIGUEZ ${ }^{2}$, J.M. GONZÁLEZ-JIMÉNEZ ${ }^{3}$, A. CAMPRUBí ${ }^{2}$, \\ J.A. ProEnZA ${ }^{4}$, C. MARChESI ${ }^{3,5}$ \\ ${ }^{1}$ Facultad de Ciencias, Universidad Nacional Autónoma de \\ México, Mexico \\ ${ }^{2}$ Instituto de Geología, Universidad Nacional Autónoma de \\ México, Mexico; vcolas86@gmail.com; \\ ${ }^{3}$ Departamento de Mineralogía y Petrología, Universidad de \\ Granada, Spain. \\ ${ }^{4}$ Departament de Mineralogia, Petrologia i Geologia \\ Aplicada, Universitat de Barcelona, Spain. \\ ${ }^{5}$ Instituto Andaluz de Ciencias de la Tierra (IACT), CSIC - \\ Universidad de Granada, Spain.
}

The San Juan de Otates ultramafic-mafic complex (Guanajuato, Central Mexico) consists of pyroxenites and peridotites formed in a Cretaceous volcanic arc root. The peridotites show different degrees of serpentinization and metasomatic alteration. These processes have produced three types of altered peridotites according to the mineral assemblages, textures and geochemistry: i) partially altered peridotites, with primary clinopyroxene and carbonate-filled veins $\left[\mathrm{CaMg}\left(\mathrm{CO}_{3}\right)_{2}\right]$, high LOI and slightly high $(\mathrm{MgO}+\mathrm{CaO}) / \mathrm{SiO}_{2}$; ii) serpentinite with pseudomorphic textures (i.e., olivine pseudomorphs and bastites), quartz filling veins, and the highest $\mathrm{LOI}$ but the lowest $\mathrm{SiO}_{2}$; and iii) birbirites with non-pseudomorphic textures, the highest concentration of $\mathrm{SiO}_{2}$ and PGE (up to $377 \mathrm{ppm}$ ), but lowest LOI.

Own results suggest that peridotites were affected by carbonatization and silicification processes subsequent to serpentinization, produced by the interaction with $\mathrm{SiO}_{2}$ - and $\mathrm{CO}_{2}$-rich metasomatic fluids, probably during the exhumation of the San Juan de Otates ultramafic-mafic complex. These fluids could remobilize elements of economic interest (e.g., PGE, Au and/or Ag), and could also be related with the formation of $\mathrm{Au}-\mathrm{Ag}$ epithermal deposit. Thus, this study could help to understand the important concentrations of precious metals in other associated deposits, as well as the origin of natural analogues for mineral carbon storage zones in peridotites. 